\title{
SHAREHOLDERS AGREEMENT: COMPARATIVE AND LEGAL ANALYSIS OF THE LEGISLATION AND LEGAL DOCTRINE OF UKRAINE, EU COUNTRIES AND USA
}

\author{
Yuriy Zhornokui ${ }^{1}$ \\ Kharkiv National University of Internal Affairs, Ukraine \\ Olha Burlaka² \\ National Academy of Internal Affairs, Ukraine \\ Valentyna Zhornokui ${ }^{3}$ \\ Kharkiv National University of Internal Affairs, Ukraine
}

\begin{abstract}
The aim of article is to conduct comparative-legal research of legislative acts establishing legal background of shareholders' agreement conclusion and execution in certain foreign states and Ukraine along with presentation of ways to improve the relevant Ukrainian legislation. Subject of research is the experience in area of legal regulation of shareholders' agreement conclusion and execution in certain foreign states and Ukraine. Methodology. Research is based on comparison of shareholders' agreement conclusion and execution in Ukraine, USA, Russia and Western Europe (Italy, Switzerland and Germany). Author defines advantages and deficiencies of shareholders' agreement conclusion and execution methodology and opportunities to implement relevant foreign practices (on the basis of comparative-legal analysis of specific provisions of civil legislation of Ukraine). Results of this research proved that in order to implement foreign experience related to legal support of shareholders' agreement conclusion and execution strict civil law sanctions must be imposed. These measures are applied in the case if there are violations of shareholders' agreement provisions. We consider that reimbursement is the most efficient and appropriate sanction for commitments deriving from the shareholders' agreements including voting procedure at general meetings, approval of voting format by other shareholders, coordination of actions related to management, key activities, JSC reorganization and liquidation due to the fact that reimbursement amount is defined by the parties and does not depend on damage inflicted, is not reduced according to the court ruling and may be applied along with other civil law sanctions. Practical implementation. Positive experience of development of legal background for shareholders' agreement conclusion and execution in certain foreign states proves that law enforcement procedures require identification of relevant agreement legal nature as for quite a long time these documents have been used by corporate relations parties. Correlation/originality. Comparative analysis of Ukrainian, European and American legislative acts regulating shareholders' agreement conclusion and execution has become a foundation for presentation of certain amendments.
\end{abstract}

Key words: foreign experience, analysis, agreement, legal doctrine, shareholders, EU states.

JEL Classification: F53, O52

\section{Introduction}

Analysis of the legislation and practice of foreign countries has demonstrated that shareholders agreements as a tool for individual and legal regulation of the relations between shareholders are admitted in many legal systems. There is a certain imbalance in the legislation of European countries. Legal acts of Italy and Russia contain provisions on the procedure for making, executing and conditions of the researched agreements. But in Germany, France and Switzerland there are no

\footnotetext{
Corresponding author:

${ }^{1}$ Department of Civil Law and Procedure of Faculty № 6. Kharkiv National University of Internal Affairs.

E-mail: sciencegens@gmail.com

${ }^{2}$ Department of Civil Law and Procedure, National Academy of Internal Affairs.

E-mail: alex0674682444@gmail.com

${ }^{3}$ Department of Legal Support for Economic Activity of Faculty № 6. Kharkiv National University of Internal Affairs.

E-mail: zvg@gmail.com
} 
special provisions for regulating the relations between shareholders through agreements. This is fully applied to Ukraine. However, legislative and regulatory compliance practices needs to clarify the legal nature of the relevant agreements, since they have long been used by the members of corporate relations. However, the legislation in many countries does not provide a clear answer both to the question about the parties, the content, the object of a shareholders agreement and its legal nature.

At the current stage of state formation Ukrainian integration to EU is acknowledged as prerequisite of further successful democratization and strengthening of civil society position (Medvedev, 2014). That is why radical social and economic transformations of the last decade led both to positive and negative outcomes for Ukraine (Pavlenko et al., 2017).

Therefore, American and European experience is so important and valuable as regulation of shareholders' relations gradually becomes a matter of great interest in the light of international cooperation and trade facilitation and orientation towards state prosperity and security.

Analysis of latest research and publications. Significant contribution to research of problems related to comparative analysis of legislative acts and legal doctrine of Ukraine, USA, Russia and EU states was made by numerous scholars: E. Sukhanov, V. Vasiliieva, E. Haymann, R. Müller, I. SpasiboFateieva, M. Sibilev, V. Yarotskyi, I. Hewitt, V. Chionna, G. Cian; Alberto Trabucchi, O. Kibenko, V. Belov, N. Kuznetsova, R. Maydanik, Y. Kokhanovskaya, T. Abova, D. Mayer, G. Stedman, J. Jones, D. Lomakin, V. Gureiev, N. Karzhavina, D. Stepanov, V. Litovkina, K. Yaroshenko, Y. Romanova, Y. Petrova, I. Venediktova.

The aim of article is to conduct comparative-legal research of legislative acts establishing legal background of shareholders' agreement conclusion and execution in certain foreign states and Ukraine.

In this regard Resolution of Plenum of the Supreme Court of Ukraine dated from October 24, 2008 No. 13 "On the practice of corporate disputes reviewed by the courts" provides that the activities of joint-stock companies (hereinafter - JSC), the relationships between the founders (shareholders), as well as issues of corporate management are regulated by laws and other legal acts of Ukraine, in particular, mandatory norms, disregard of which violates public order (p. 8-9).

However, despite the opposition expressed by some experts concerning the application of the researched legal category within joint-stock relations, we have to note that the concept of "joint-stock transactions" was first legalized by the Law of Ukraine "On JointStock Companies" (we use the term of "transactions between shareholders") (On Joint-Stock Companies, 2008). Such an allocation of the group of contractual obligations by the national legislator borrowed from the Anglo-American legal system, where the joint-stock transactions they understand agreements between shareholders on the management of corporation, voting procedure, contains restrictions on expression of will and other use of the corporate vote (Vasylieva, 2008).

Shareholders agreements are known to German law, which is close to Ukrainian law. The German law allows the concert between shareholders to vote at the general meeting by concluding the agreement (stimmbindungsvereinbarung) (Spasybo-Fateeva et al., 2014). Analyzing the German, French and Italian professional literature on the formation of doctrines on shareholders agreements we may observe in each case that the emergence of such contractual relationships is the result of the formation of the doctrinal foundations of their appropriateness and legality. It mainly concerns such an aspect of corporate relations, as the issue of voting compared to the demand on the freedom of exercising the rights in one's sole discretion.

Certain German experts in the middle of the XX-th century maintained their points of view of the admissibility to disclaim and limit own will and interest of the rights that is derived from participation in a business entity. It is stated that the coherence of a member of a company, in case of concluding the agreement on a certain way of voting, shall not be considered during the voting at the general meeting as more than a contradiction of his freedom to vote by any way, but rather it is an expression of his freedom (Fischer, 1953; Weber, 2000).

Shareholders agreements are common in the corporate practice in Switzerland. Their legality and admissibility is admitted by most scholars and court practice. Analysis of doctrinal and practical research in this country leads to the conclusion that over a long period of existence of this problem as an object of research and practical interests, there is a sufficient scientific and practical understanding of the role and significance of shareholders agreements as a tool of accessory regulation and protection of corporate interests of shareholders (Aktienübernahmevereinbarungen zwischen Mehrheits und Minderheitsaktionären: ein Vorschlag $z u$ einem wirksamen Minderheitenschutz, vor allem in kleinen und mittleren Aktiengesellschaften, 1973).

Legislative foundations for the possibility of concluding shareholders agreements in Switzerland are general norms of contractual and corporate law. The Art. 27 of the Civil Code of Switzerland, which proclaims the principle of freedom of an agreement and inadmissibility of excessive obligations, should be called as the general basic norm of civil law. This principle is determining both for using shareholders agreements and for establishing the limits of their specific content.

It is historically that in France there is somewhat different situation for the recognition of the possibility to conclude a shareholders agreement. Thus, agreements between the shareholders of the duty to vote in a 
certain way were banned in France. It is associated with the understanding of the role of a shareholder, who participating in the general meeting shall decide on the basis of free will principle (Sonnenberger, 2000). Later in court practice such agreements were admitted, but with certain restrictions, in particular concerning the timing of their action and content.

In England shareholders agreements regulate relations arising in connection with the management of the company, establish the dividend policy, are aimed at addressing "deadlock resolutions", may impose restrictions on the disposal of shares: call option, put option, pre-emptive rights on acquiring shares by the shareholders, lock - up provisions, tag along rights, drag along righs (Hewitt, 2016).

Italy is one of the few EU countries, where the civil law contains special provisions aimed at regulating the procedure of concluding shareholders agreements. Such a decision of the Italian legislator was not a reflection of general European tendencies (Chionna, 2008). Italian experience in regulating shareholders agreements is of particular interest for studying this issue because we can observe the characteristics along with the fact of the presence of special norms of the civil law on such commitments, indicative, in particular to the norms of other states, such as the Art. 32.1 of the Law of the RF "On Joint-Stock Companies". This is due to the fact that many provisions of the Italian civil law on this issue were borrowed by Russian legislator concerning a joint-stock company.

In legal doctrine presented approaches were not unequivocal supported. In particular, Ye. O. Sukhanov asserts that a shareholders agreement according to its legal nature is a civil and legal contract on exercising shareholders' rights, not a "corporate transaction", which determines the structure of the corporation's management (Suhanov, 2014). V. A. Bielov does not support the position about a "clean" contractual nature of the researched relations between the shareholders indicating that they (relations) should be considered as "unilateral half-directed transactions with a plurality of persons on the side, which exercise them" (Belov, 2013).

There is a question whether shareholders agreements are the kind of civil and legal contracts, or whether they are independent type of contracts governed by the Civil Code of Ukraine, but being outside the civil law, and are the object of other area - corporate law, the object and method of which are under the scientific discussion for many years.

Binding and legal rather than corporate nature of the shareholders agreements is generally admitted in European corporate law. Derived from here is their binding nature only for persons who have signed them, but not for the whole corporation. Thus, in case of violation of such an agreement by one of the shareholders, contractual responsibility can be relied on him, but the results of voting and decisions taken by the company are legally valid and can not be challenged.

In Germany and Switzerland the shareholders agreements, usually are not considered as an independent type of agreement. The prevailing view is that it should be understood as agreements of shareholders that regulate legal relationships of the shareholders or groups of shareholder between each other (Mayer, 2006). The basic norm that determines the admissibility of the shareholders agreements under German civil law, is the provisions enshrined in c. 5, $\$ 23$ of German Law “On Actions" (Aktiengesetz vom 6. September 1965), under which "provisions supplementing the charter of the company are admissible, if the law does not contain an exhaustive regulation".

The shareholders agreements in German legal literature and practice are almost unanimously qualified as agreements on common activities and are regulated by $\int S$ 705-740 of the German Civil Regulations on the agreement of partnership. However, it should be noted that the shareholders agreement in the form of "partnership" can solely exist, when its parties are only individuals, who do not have the status of entrepreneurs. In other cases, such agreements are considered as binding and legal agreements on the ways and peculiarities of realizing the rights to shares and rights from them and are regulated by the general norms on contracts. Similarly, this issue is solved in Swiss legislation, which recognizes several forms of real expression of the shareholders agreements: single and double sided binding agreements, a partnership agreement (Müller, 1998). The latter in most cases is the basic form of fixing binding relationships between the shareholders.

Analyzing the experience of legislative regulation of the shareholders agreements in Germany, Switzerland, France, one can conclude that, firstly, these countries do not use legal concept - "corporate agreement". None of the countries of continental Europe does not apply the legal terminology of foreign countries in its legislation, including legislation on joint stock companies (exceptions are Latin terms and names of some legal institutions that are quite specific to any country or the group, such as the concept of "trust"). Anglicisms, which are followed by the modern adjective "corporate" may be used only as a doctrinal concepts. National legislator and the corresponding doctrine analyze, compared and receive legal structures used in other countries - it is a natural process of international and interstate legal communication. However, we seek to use legal concepts that are specific to the national language. Thus, the Art. 2341 bis of the Civil Code of Italy uses the term "Patti parasociali", which is literally interpreted as "an agreement concerning the company". Herewith the Italian legislator does not use the adjective "corporate" («corporativo»), because the word "corporation" is used in a rather narrow sense, as a rule, to refer to groups 
based on membership, sometimes without a legal entity, for example, trade unions.

The legislation of most countries in Europe does not contain a legal definition of the shareholders agreement. The exception is Italy, which civil law designates such agreements in different ways, including both the term "shareholders agreements", and other terms that emphasize the variety of such agreements according to their nature and spheres of application. In particular, the shareholders agreement are designated as patto parasociale (also contratto parasociale). Besides such term as sindacato azionario is used. It means agreements of shareholders with the terms for selling the shares. The term sindacato di blocco is used to state the type of shareholders agreements providing specifically only the condition for not selling the shares.

Thus, we can specify that the legislation of European countries does not generally contain the definition of the category "shareholders agreement" that is because of the fact that the corresponding construction has found its development and grounding within court practice and legal doctrine. However, the absence of such a definition only makes embarrassment, because does not allow to give a definite answer to some questions - one of which is the subjective matter - the parties under such an agreement.

There are three approaches to the establishment of the parties of the shareholders agreement. They are: 1) shareholders only (Lomakyn, 2008; Suhanov, 2014); 2) shareholders and a company (Hureev, 2007; Karzhavyna, 2007); 3) shareholders, the company and third parties (Spasybo-Fatieieva, 2009; Stepanov, 2013).

Paying attention to guarantees of the minority shareholders, Yu. V. Romanova indicates that shareholders agreements under the laws of France, the United States and other countries, are concluded between the shareholders (Romanova, 2004). Despite the fact that corporate law does not literally establish that it is the company or third parties, who are not its shareholders, can be a party to such an agreement, but still we need to recognize that neither the company nor persons who are not its members can be a party to the shareholders agreement under current regulations, there are no corporate relations outside the legal entity.

The second position related to the definition of the subject matter of the shareholders agreement is limited to the fact that it can be concluded between the shareholders or between the shareholders and the company, as the shareholders agreement signed only between the shareholders does not obligate the joint stock company to anything, which in turn, makes little sense in the agreement itself (Hureev, 2007; Karzhavyna "Shareholders' agreement as a way of corporate conflict overcome and the problem of its validity under the Russian”, Business Law, 4 (2007).
Why is there a need in practice to include a company among the parties of the shareholders agreement? According to D. I. Stiepanov, it is for the reason that the bodies, which are derived from the general meetings of the corporation members through the corporation that is involved in this agreement as the party, had to be obliged to fulfill decisions taken by its members. Typically, the scholar continues, the company may be a party either of an agreement, where all of its shareholders take part, or an agreement, which involves not all the shareholders, but where the corporation receives only the rights, but bears no obligations to other parties of the agreement (otherwise the rights of other shareholders, who do not participate in the agreement could be violated in favor of the parties to the agreement) (Stepanov, 2013).

This approach is confirmed by the international legal practice. In particular, provisions, by which the company becomes a party to a shareholders agreement, are more common in England (Stedman, Jones, 1998).

It is worth paying attention to the existence of the third approach. Thus, I. V. Spasybo-Fatieieva believes that the shareholders agreements relate to the concert between the shareholders (Spasybo-Fatieieva, 2009) ..., however, continued her position, notes that not only the shareholders can be their subjects, but also future shareholders (investors) (Spasybo-Fatieieva, 2009). Instead, O. M. Vinnyk offers acknowledge founders, shareholders and/or potential shareholders - persons, who subscribed for shares of additional issue, as the parties of the shareholders agreement (Vinnyk, 2010).

The main reference of the supporters of the third approach is the fact that the company lenders and other third parties may enter into an agreement with the shareholders, whereby the latter, in order to guarantee the interest of third parties protected by the law, undertake to exercise their corporate rights in a certain way or to abstain (abandon) their implementation, including, to vote in a certain manner at the general meeting of the company members, to take other actions to manage the company, to acquire or dispose the shares in its authorized capital (shares) at a specified price and (or) under certain conditions to refrain from alienation of a shares (interests) to the occurrence of certain circumstances. The rules on corporate contract are applied to such an agreement (Abova, 2013).

Let's study these approaches. Since the shareholders agreement has the appropriate name, the first thing making any associations - is its recognition by the parties of only the shareholders. As we have already noted, the number of shareholders who conclude the shareholders agreement may be any, besides these can be both majority and minority shareholders, who have decided to protect their rights by consolidating their capabilities, these can be shareholders - individuals or shareholders - legal entities, these may be only two shareholders or all shareholders of a company without exception. It is obvious that only the shareholders are 
the parties of the shareholders agreement, only they acquire the rights and obligations under this contractual structure, execution of which is realized through the implementation of actions by the shareholders, the most common of which is the transfer of property and advance voting in a certain way.

The shareholders in a joint stock company are not in legal relations between each other, but the latter may arise between them, if they conclude an agreement. In this case, there will exist two kinds of legal relations in a joint stock company - between a joint stock company and each shareholder (corporate) and between the shareholders who entered into an agreement (contractual). The latter include not all the shareholders, but only those who signed the agreement. It does not act for the rest of the shareholders. Therefore, the execution of such an agreement should be made by those shareholders, who are its parties (SpasyboFateeva et al., 2014).

The proposition to participate in this agreement for both the company in the whole (herewith, the decision will be determined not by all of its shareholders, but only the parties of the shareholders agreement) and any third parties, including those, who did not buy the shares of a company (was not involved in the formation of the company's property), but got essentially unlimited ability to determine the decision of a joint stock company, is not reasonable. We believe that even if these third parties will be lenders of a joint stock company, their crucial part in the affairs of a company is able to make no sense for other shareholders to participate in it, not even mentioning the fact that the interests of third parties and shareholders are not identical.

European continental law does not usually recognize the opportunity of third parties that are not shareholders to participate in the shareholders agreements. Since these are only the shareholders, who determine the purpose of its activities, and fix it in the statute and determine its fate, thus, only they have the right to participate in shaping the will of a company (and third parties by obtaining mastery over the votes of the shareholders may get the opportunity to influence the decisions of the corporation, the risk and the consequences of which take the shareholders of a company, but no the third parties). Negative attitude to participation of third parties in the shareholders agreements is also due to the fact that they are excluded from the traditional corporate responsibilities to act in good faith and in the interests of the corporation in the whole (Suhanov, 2014).

Instead, third parties according to English legal practice (potential buyers of shares) may be parties of the shareholders agreements obliging themselves by the provisions of an agreement of shareholders by signing the deed of adherence (Petrova, Khrapov, 2008). Founders of a company often seek assurances that while the alienation of shares by anyone of them, a new purchaser will be bined with the terms of the shareholders agreement, and thus, the prolongation of the direct contractual nature of relationships between all the stakeholders will assured. Accordingly, the shareholders agreements subordinated to English law, almost always include a condition that the registration of the fact of transfer of shares into the property to another person may occur only under the condition of joining a new owner to an existing shareholders agreement by signing the deed of adherence. In case of the alienation of a small number of shares by one of the members of the shareholders agreement, other shareholders-parties may require restrictions of the deed of adherence to obligations on the compliance with some certain provisions - such as the conditions on confidentiality, obligations not to be engaged in competition, certain obligations related to decision-making and voting, etc.

We believe that the company can not be a party to the shareholders agreement because it does not have the status of a shareholder and can not be a shareholder of itself. In the case that it bought the shares of its own issue, they are "dumb" until their alienation to already existing shareholders or third parties. Besides this possibility could bring to life "circular reference" - the management of the company subordinated to shareholders should ask their permission for the inclusion / non-inclusion of any condition of the agreement.

We should express some doubts regarding the recognition of potential investors as parties under the shareholders agreement. If we accept the possibility for third parties to participate in the conclusion of the shareholders agreements, we should also recognize the expansion of limits of shareholders relations that would come out the limits of a joint stock company. If we agree with the fact that the company creditors have the right to direct the actions of the shareholders of a particular company in the interests of third parties, thereby affecting the management of a company, would this situation cause the management of a company not by its shareholders, but by third parties. On the one hand this possibility is aimed at ensuring the interests of creditors and on the other - there is a question if the application of such a norm would lead to the occurrence of negative effects such as violation of corporate rights of the shareholder by persons, who are not members of shareholders relations, corporate capture or acquisitions, corporate conflicts.

The issue of the content (terms) of the shareholders agreement and especially its object is still very urgent. To clarify this issue we should refer to the law and legal doctrine of European countries.

In countries, where the shareholders agreements as a legal structure are recognized at the legislative level (Italy and Russian Federation), the norms focused on their regulation, contain the list of the obligations that may be the object of such agreements. However, the regulation of the object of the shareholders agreements has fundamental differences. In general, the legislation 
of these countries contain similar obligations, but if the norms of Russian legislation regarding the types of specific obligations have the nature of a possibility (the Art. 32.1 of the Law of Russian Federation "On Joint Stock Companies"), the norms of Italian law unequivocally confirm that only obligations listed in the Art. 2341 bis of the Civil Code of Italy may be the object of such agreements. Besides, the structure of the p. 1 of this Article makes it possible to conclude that only those agreements, which provide the obligations listed respectively in points a) - c), may be recognized as the shareholders agreements, if they are concluded for the purposes set out in the same norm. Thus, the shareholders agreement in Italy can not contradict the mandatory norms of the law, its object is very limited.

Regarding the object of the shareholders agreement within English legal literature it has been noted noted that the main objective of joining it is the regulation of corporate rights and obligations of the shareholders both under the conditions of executing shares' sale and purchase agreements, and during the creation of joint enterprises, including international ones (Osypenko, 2010). Thus, the shareholders agreements on the territory of the United Kingdom, except the norms similar to the standards of memorandum, usually contain a more detailed description of the objective and scope of activities regarding joint ventures, procedure of financing the company and agreed on shareholders' deposits in non-cash form; policy of profit distribution (Makarova, 2010).

Such agreements in the French corporate law can generally refer only voting of shareholders and only during specific meetings (not during any period of time) and subjected to other serious limitations (Sukhanov, 2014).

Specific types of obligations that may be the object of such agreements are describe more differentiated in Germany and Switzerland. This is due to the fact that authors, as a rule, list the specific typical kinds of obligations, which are the basis for the conclusion of the shareholders agreements. Their detailed analysis demonstrates that they are covered by such types as the obligation to exercise voting rights, obligations to the features of the alienation of shares and obligations to the company. There are also atypical cases, but they are not common in the practice of concluding the shareholders agreements. These include obligations to third parties, not the shareholders about the transference of the rights, etc.

The German and Swiss legal doctrine offers to allocate such types of obligations that may be the object of the shareholders agreement, as a) to vote at the general meeting in a certain way, for example, only together under the previous concert or according to the suggestion of one of the parties; b) to sell shares only under certain conditions, for example, only by the consent of other shareholders; c) obligations to grant the right of preferred purchase under the pre-set price, in case of selling the shares; $d$ ) to provide (retreat) to a third party, for example, the voting rights to a creditor of the shareholder; e) to provide one of the shareholders the right to appoint his representative to the supervisory board, irrespectively to his share (Mayer, 2006; Schramm, n. d.).

The Law of Ukraine "On Joint Stock Companies" does not contain clear indication on the aspects of the company's activities and specific actions of the shareholders that should be the object of the shareholders agreement. The bill No. 4160 dated from February 26, 2016 "On Amending Some Legislative Acts of Ukraine on Corporate Agreements" has defined the object of such an agreement, which may be the realization by the shareholders their rights to shares and/or the rights under shares, as well as laying duties according to own will of the shareholder - the parties of the agreement, leading to the conclusion that the shareholders may agree to establish a special procedure for decision making by the general meeting or the procedure of formation and activities of the executive agencies, supervisory board, to determine the procedure of conflict resolution, etc.

Based on the principle of the freedom of the agreement, the shareholders-parties of such an agreement have the right to agree on the validity term and correspondantly specify the exact day of its termination (or the event that terminates it). In practice, the parties may establish any validity of the agreement and predict the circumstances entail the automatic its termination (for example, liquidation of the company, its reorganization, bankruptcy, etc.). We believe that more effective measure to plan the termination of the agreement will be the establishment of its validity or classical way of termination - concert of the parties.

The form of the shareholders agreement. Freedom of the agreement in corporate law may be subject to limitations as according to the content, as under the reasons depending the document or the form it should be expressed.

Shareholders agreement is concluded in written form by drawing up one document signed by the parties. This approach is, in general, traditional. However, it should be noted that in Germany and Switzerland it is allowed to conclude such agreements also orally. In accordance with p. 2, c. 1 of the Art. 32.1 of the Law of Russian Federation "On Joint Stock Companies", the shareholders agreement is concluded in a written form by drawing up one document signed by the parties. As a consequence of non-compliance with simple written form of the agreement entails its invalidity.

English law also does not require a specific form of the shareholders agreement, but in practice it is concluded in a simple written form or in the form of «deed $\gg$. Oral shareholders agreement according to English law is theoretically possible but in practice can not be applied. 
If the parties of such an agreement under English law are legal persons, they can sign the agreement in two forms: 1) simple written form. For its adherence the shareholders agreement must be signed by a person authorized by the Supervisory Board. Typically, this is one of the members of the executive body, but may be another person who has any document confirming the authority to sign;

2) «deed» form (while concluding the shareholders agreement according to this form there are different options):

a) sealed by the companies - parties to the agreement and signatures of the persons authorized by the constituent documents (signatures of two directors or secretary and director of the company or other persons authorized by the Supervisory Board);

b) the signing by two directors or a secretary and director of the company in the presence of a witness. The witness also must sign, specifying the address, place of work and position (according to the Art. 44 of the English Law on Companies, 2006).

c) signing according to the proxy notice (in this case the proxy notice must be made in the form of $\ll$ deed $\gg$ ). If an authorized (trusted) person is an individual, his signature must be placed in the presence of a witness (who must also put the signature, indicate his address, place of work and position). If the trustee - another legal entity (company), then it must fulfill all the same formalities as if the document is signed on its behalf. However, in both cases, an authorized (both individual and legal entity) person is obliged to notify that he acts on behalf of another person according to the proxy notice.

In all cases the document must specifically state that it is $-\ll$ deed $\gg$. If it is assumed that the document («deed $\gg)$ does not take effect until the specific moment or event in the future, thus containing a pending condition, this fact must be due to the parties - mainly to avoid doubts or disputes in the future, in a written form through correspondence, presentation in a separate document, etc. In the absence of any indication on this intention of the parties will be deemed that «deed $\gg$ came into legal force immediately after realization of all formalities.

Consequently, the shareholders agreement is concluded in a written form by drawing up one document signed by the parties. Shareholders who signed it are obliged to inform the company about the fact of its conclusion. In case of default of this obligation the shareholders who are not parties to the shareholders agreement, are entitled to demand compensation for their losses.

Content of the shareholders agreement creates a set of the rights and obligations. There is a question: how agreements are brought into accord between shareholders (those rights and obligations provided by them) with corporate rights, rights for shares and rights from shares that are limits of acceptability restricting shareholders' rights, which are established by the agreement and ultimately lead to their inequality and whether they are valid.

It is rather difficult to provide the exact definition of "deadlock provisions", owing to the lack of a unified approach to its description. In general, it is characterized as the inability to achieve the consent by the shareholders on key points of the activities of a joint-stock company. It often occurs, when the shareholders have different views on the issues of forming management agencies, spending the profits, determining the strategy of the company's development. To resolve deadlock provisions there are various options for action. Let's pay attention to some of them.

Russian Roulette. Quite comprehensive solution, which main point lies in the fact that in the case of "deadlock situation" one or both shareholders make another shareholder the proposal of repurchasing the half of already priced joint-stock. The shareholder who receives such notification has the choice to cell his stock for the marked price or, conversely, to buy the other shareholders' stocks for same price.

Texas Shoot-out. Each shareholders' agreement party which is in the "deadlock situation" forwards to independent mediator sealed proposal for price to buy another parties' assets. The envelopes are opened simultaneously and the highest price bid wins, so the person who made it has to buy and the other side has to sell its shares for price as marked.

Multi-choice procedure. This mechanism is milder in comparison with referenced hereinabove. It is used when parties don't want to enter into an obligation of severe and concrete deadlock situation solution. For example, this mechanism can provide specified set of predetermined options one of which will be chosen in fine. The advantage of such method is that parties in view of irreversible consequences connected with shares loss could act more reasonably and find the compromise solution. But the disadvantage of this model is than in case of effective negotiation process and final arrangement absence the process can draw down and affect the company activity. The parties would be bound to resort to arbitration which would decide what option has to be used. This circumstance brings some uncertainty in deadlock situation solution.

Cooling-off (mediation). Its main point is that shareholders stipulations provide the parties' duty to carry on negotiations using an outside mediator till the decision won't be found. If the mutual decision won't be found through the process of negotiations, the so called judgment of Solomon should be taken by mediator on the basis of principle of reasonableness. From the first glance this method is mild but there is a possibility that the judgment of Solomon will be that parties should wind up a company as far as they failed to solve the dispute by negotiations. 
Deterrence approach. This mechanism should detain the parties from solving the deadlock situation by withdrawal of one party from shareholder's composition without resolving of disagreements by discussion. This is achieved by including in the contract, in a certain sense, onerous regulations for the party, which nevertheless initiates this procedure. Instead of activing negotiations proposition and subsequent statement of impossibility to make a decision on key issues this party can come straight to the notifying about the deadlock situation. In this case the party which forwarded the notification should either buy out the other side shares for $125 \%$ of their fair market price or sell its' share to the other side for $75 \%$ of its fair market price. This value is determined with the assistance of appraisers and auditors. Such mechanism is still not always effective because on the one hand it excludes negotiations as method of discrepancies elimination and on the other hand maintains certain parties' interests balance violation that could paralyze the activity of the company.

Parties' responsibility by the shareholders agreement. Civil legislation highlights five main forms of responsibility: restitution, compensation of moral harm, penalty payment, loss of downpayment, compensation payment. However, those measures are difficult in applying to the parties of share agreement. Because of that, in practice are traceable cases of other forms of responsibility application inherent in foreign law, such as compulsory shares sale. For example we can give a shareholders agreement between Swissport International Ltd, ZAO "Airline" Ukraine International Airlines", Airline Business Handling Limited where was pointed the question of voting at the general meeting and the result of nonobservance was the duty of one party to dispose its' share in favour of other party, this became the responsibility measure for disregard of provision. However, both science and practice gives ambiguous answer to the question: whether it is appropriate to provide an opportunity to attach in provisions of such agreement measures (forms) of responsibility not foreseen by civil law and, consequently, the possibility of judicial protection of the parties in the case of failure or improper performance of their obligations under the joint stock contract?

By the shareholder agreement may be provided measures of civil liability for its failure or improper fulfillment. Separate question is responsibility for dereliction of such duties because art. 29 of the Law of Ukraine "On Joint Stock Companies" says only about shareholders' responsibility for breaking the duty of participation in the general meeting. Clumsy phrasing of this provision may affect the addressing of the issue of bringing to responsibility shareholders for the failure to fulfill other obligations established by the agreement between them.

One of topical issues is one about possible consequences of shareholders agreement nonfulfillment, particularly, ways to protect shareholders' corporate right in case of such agreement breach. In case of its violation by one of stockholders on him can be imposed a contractual liability in form of obligation to compensate damages to other parties or pay the agreed in advance penalty, but the results of voting and corporate decisions remain legally enforceable and can't be contravened on that basis.

According to English law shareholders agreements are assured by court defense as a usual contractual obligation. Thereafter, shareholders' protective means in case of provisions violations are: a) liquidated damages levy - in English contract law damages are not punitory but compensatory, in other words it don't have the penal character; b) specific performance - demand of stipulated by the contract obligations fulfillment; c) injunction for specific activities interdiction (injunction).

In this case certain treaty provisions (warranties) give the shareholders right only for restitution, whereas other (conditions and representations) give the right for restitution and voidance of contract.

Although Italian and Russian legislations contain a reference to the norms of Civil legislation, but orient to use common methods of collateral for commitments taking into account the specificity of obligations which originate from shareholders agreement. Italian practice uses such methods of obligations collateral as forfeit, pledge of shares. In Russian Federation, on the contrary, only some measures which can be used in case of nonexecution of shareholders agreement exist: a) reparation of damages, caused by its infringement; b) award of a penalty, fine, mulch; c) payment of the consideration (firm amount or amount that should be defined under procedure outlined in shareholders' agreement); d) imposition of sanctions resulting from agreement infringement.

One of substantive issues of shareholders' corporate rights protection techniques is possible consequences of shareholders agreement nonexecution. As a result of such agreement institute integration to the corporate practice appears an opportunity for shareholders to protect their interests at the contractual level, that is now used insufficiently.

Mandatory duties performance in kind. The Law of Ukraine "On Joint Stock Companies" contains no express statement of possibility to specific performance (for example, make the shareholder to vote at the general meeting in a certain way). For the aim of defining the ability or inability to claim for specific enforcement at the fore should be the condition of obligation after the violation happen to be. Nonperformance (improper performance) of duties according to the shareholders agreement by stockholder can cause: 1 ) the termination of obligations and abandonment of it unfulfilled, 2) the existence of delay in execution of shareholders agreement. Agreeably, claim for specific enforcement 
can be brought only in latter case, in other words, in case when shareholders whose rights were infringed does not take actions that could be interpreted as a waiver of joint stock agreement or acceptance of defective performance.

In case of non-property liabilities infringement, envisaged by the joint stock agreement (for example, shareholders refusal from voting in specific way and so on) specific performance is inadmissible in case of: a) such liability has strictly fiduciary nature; b) such liability is hard to fulfill both from the perspective of real possibilities shareholder who has violated shareholders agreement and in terms of court decision implementation; c) claim to complete this obligation is not brought within a reasonable period of time after shareholder whose rights were violated by nonperformance or improper performance of shareholders agreement came to knowledge about committed violation.

Foreign legal literature, concerning the issue of application of liability measures for shareholders agreement violations, a long time already is recognized possibility of judgment for specific performance in case of such agreement terms violation. In particular, $\mathrm{H}$. Appenzeler considers in detail the problem of this measure application and admits that his party whose rights have been violated, may fundamentally require not only compensation of caused damage, but also actual obligation performance (Appenzeller, 1996). A similar point of view expresses R. Muller, noting that as one of the measures of responsibility, in case of shareholders agreement violation can be used claim for specific enforcement (Müller, n.d.). P. Forstmoser also declares the right to claim for specific performance by party which violated shareholders' agreement measures (Schluep, Forstmoser, 1988).

Specific enforcement is not an appropriate mean of protection, because there are no mechanisms which would allow to force him to vote, for example, like it's stipulated in the agreement, as if it could be possible in some another agreement. There is also absent the possibility to put into use such consequences as consider the shareholders-parties of the agreement will automatically expressed during the voting, for which reason, no matter in what way he voted, consider his vote given for adoption of a decision for which he was obliged to by the agreement. Along similar lines is not acceptable during the shareholders vote count on the result of voting to check whether the vote of shareholder who signed the agreement corresponds the obligation he's assumed by voting in a certain way.

Recognition of the transaction invalid and application of the consequences of its invalidity. In contradiction from Ukrainian joint stock legislation Law of Russian Federation "On Joint Stock Companies" (P. 4 of Art. 32.1) expressly provides that agreements committed by a failure to comply with conditions of share agreement are disputable. For example, if for the purpose of agreement violation party commits the shares disposal before a certain event, this purchase agreement could be invalidated by judicial procedure on the claim of its other side, if it's proved that buyer knew or must be taken to have known about set restrictions. Considering that the content of shareholders agreement parties correspondence (including limitations foreseen there) de jure shall be kept confidential a need in efforts arises in order to prove in court that the third person knew or should have known about the limitations stipulated in the contract. From the practical point of view it would be appropriate to consider that moment and provide in certain agreements some provisions containing warranties of relevant agreements noninfringement and also establish measures corresponding to parties' liability.

Invalidation of general meeting decision. Such method of violated rights defense is not quite new to corporate law. The share of legal controversies on invalidation of extraordinary and annual shareholders general meetings and as well as meetings of joint stock company supervisory board are almost half of all the joint-stock disputes being considered by the courts. To solve them the Resolution of Plenum of the Supreme Court of Ukraine dated from October 24, 2008 No. 13 "On Practice of Court Consideration of Corporate Disputes" is used successfully enough (Resolution of Plenum of the Supreme Court of Ukraine, 2009). In this regard it seems to be explicable to capture this method of violated right protection in the Art. 16 of Civil Code of Ukraine. However, to answer the question about the possibility of its application in case of shareholders agreement breach is not so simple as it seems at first glance.

On the purpose of keeping a balance of interest between shareholders and third parties Law of Russian Federation "On Joint Stock Companies" establishes that shareholders agreement violation can't be the foundation for invalidation of company bodies' decisions. Thus, if agreement is established as a result of company decision making (these are significant company transactions and interested-party transactions) then it shouldn't be considered invalid, even if its settlement breaks shareholders agreements' treaties. So, if, presumingly, shareholders agreement settles the duty of all shareholders to vote at the general meeting in a certain way and this duty is infringed, for example, by stockholder who has controlling block of stocks, it's impossible to consider this decision invalid because of agreement unfulfillment. The only possibility for stockholder whose rights will be infringed is to claim for usage of penalties to shareholder-violator, of course if such measures are stipulated in the agreement. This regulation will be logical ending for the rule that shareholders agreement is obligatory only for its parties.

So, such an agreement, for one thing, sets aside of corporate law regulations and, for another thing, 
can't create any legal effects for third parties including company personally, stockholders who didn't take part in that, company contractors. This position is not one and only. In foreign legal doctrine significant expansion has approach, supported by Russian law scientists as well, which insists on necessity of giving the possibility for shareholders of non-public corporations to influence the relations within the corporation. Law, for example in USA and the Netherlands, recognizes the permissibility of non-public corporations' shareholders to asset agreements aimed at changing the legally established regulations governing internal relationships in the corporation. Among practice lawyers exists the opinion that legislator shouldn't exclude the possibility of influence of shareholders agreements' violation on validity of company bodies decisions so peremptory. The decision about permissibility or impermissibility of such position should be decided taking into account type of stockholders relationship and whether the rights and interests of third parties are affected by decision made with breach of an agreement. If we are talking about, let's say, about JSC which structure is built by closely held corporation model (where is small amount of shareholders and company shares are disallowed for trading) which has strong element of shareholders personal participation in company affairs, their actions are coordinated and interest are pretty equal, in that case arrangement violation could have influence for decision validity measurement.

Invalidation of shareholders general meeting decision in relation to adoption procedure violation: shareholders voted for decision in violation of undertaken by agreement obligations to vote in a certain way (for certain candidate for some position and so on) according to I. V. Spasybo-Fatyeyevoyi appears to be unacceptable protective measure as far as consequences of unfulfillment of an agreement by shareholders (arrangements for voting at the general meeting) should ensue only for this arrangement parties but not for the rest of shareholders. But general meetings decision causes consequences for all shareholders and its invalidation irreversibly will have an impact to all shareholders and JSC itself (Spasybo-Fateeva et al., 2014). That's why fulfillment or unfulfillment of shareholders' agreement can't be the reason for general meetings' and other company bodies' decisions invalidation.

The restitution can't always be adequate measure against shareholders' agreement nonobservance because of its proving complexity. Thus, according to Art. 16, 611 of the Civil Code of Ukraine, the party which violated the obligation must compensate the other party inflicted losses - actual damage, as well as loss of expected profit. Upon the request of damages recovery plaintiff must prove the wrongfulness of inflictors' behaviour, his guilt (in accordance to requirements of art. 614 of the Civil Code of Ukraine), nature and extent (assessment) of adverse consequences, cause and effect relationship between actions (inactions) of the offender by the consequences occurred. According to the content of the above-mentioned norms of the Civil Code, damages, being property losses, are the subject of proving in every specific case of its' infliction. For shareholders whose rights were inflicted by shareholders agreement unfulfillment it will be quite difficult, and sometimes even impossible, to prove the fact of damage infliction and to determine its amount. For example, actions of shareholder who sold shares to the third party in disregard of prohibition established by shareholders agreement for its' off-load within specified time, undoubtfully, will cause negative consequences for other agreement parties making more complicated implementation of company projects, putting under threat the company achievement of previously set targets and tasks that may cause the risk of failure to obtain dividends by shareholders, may lead change of the Supervisory Board and (or) the sole executive body and so on. However, it will be quite difficult to prove cause and effect relationship between such shareholders actions and possible negative consequences for other parties of this agreement as well as estimate the amount of expected profit loss.

In the opinion of R. Muller, in order to secure the obligations that are derived from the shareholders' agreement, it is possible to apply such methods: a) contractual penalty; b) deposit of shares; c) pledge of shares to cover contractual penalties; d) transfer of shares to the common ownership of the respective shareholders; e) contribution of shares into holding company; f) transfer of the authority to the representative - the third party, who exercises the rights and obligations stipulated by the shareholders agreement; g) transfer of shares to the trust management of an independent third party or several persons; h) establishment of shares purchase pre-emptive right in case of agreement violation; i) establishment of majority decision voting procedure among persons participating in the agreement (Müller, n.d.).

Contractual penalty usage is one of the most popular measures of derived from shareholders' agreement obligations collateral. However, a significant disadvantage of using this means of securing obligations is the fact that the forfeit amount can be reduced in a judicial proceeding. Besides, considering the fact that the consequences of such agreement violation mostly can't be valued in monetary terms, it's not so obvious which forfeit could be "commensurable" with the consequences of obligation infringement. We believe that the forfeit will be an effective mean of the obligations fulfillment insurance utility if shareholders agreement prescribes such parties obligations as purchase or dispose shares by predetermined price and (or) in case of some circumstances occurrence to retrain from shares disposure till certain circumstances occur. 
The possibility of using the majority of effective methods on ensuring obligations' performance depends on the parties' ability to entrench the amount which should be payed in case of nonexecution the shareholders' agreement obligations, particularly, the amount of forfeit. It allows to use such methods of obligations fulfillment ensuring as, actually, forfeit, pledge and also guarantee. Shareholders agreement should be secured by the measure which definitely allows parties to predict the consequences of performance failure or its improper performance. That is what determined the appearance of such method of responsibility for this agreement violation as compensation, which remains firm and fixed amount that should be payed in case of agreement breach.

Compensation for shareholders agreement violation has purely warranties nature which provides proper obligations performance provided by this agreement. It is necessary to point out that appearance of such responsibility measure as compensation appears to be the implementation of one of the basic Civil law principles - freedom-of-contract doctrine and its real enforcement. Upon that bona fide shareholder receives the possibility to decompensate not only losses but also moral harm which evolves unprejudicialy.

One of the most up-to-day and the most complicated questions connected with the usage of compensation in case of shareholders agreement violation is question about possibility of decreasing the compensation amount in legal proceedings. Compensation should be correlated with a monetary assessment of the adverse consequences of obligation breach. There are not foreseen and cannot be foreseen all possible measures of identifying the amount of caused harm because of variety of relevant actual facts of obligation breach. However, in each specific case the shareholder who goes to court for protection of the violated right and demands vindication of the compensation from violator should justify not only legality, but also economic expediency of settlements procedure offered by him that sometimes appears to be difficult, especially while calculating the expected profit loss. That's why legislator provides parties of shareholders agreement the possibility to assess beforehand and in their own right the amount of losses that can be caused by each specific violation of such an agreement.

In our opinion, compensation is the most universal and effective measure of responsibility of the parties to the shareholder agreement. First of all, compensation is established by the parties and can not be reduced at the court decision. Secondly, for its appliance there is no need to prove the existence of losses. Thirdly, the compensation recovery does not exclude the possibility of restitution in case of their existence.

To protect the shareholders' rights in case of shareholders agreement infringement and exclusion of legal uncertainties in the matter of applying the compensation in corporate law, it seems advisable to add to the Art. 29 of the Law of Ukraine "On Joint Stock Companies" by the regulation about if the regulations of a shareholders agreement are violated, the guilty party should compensate affected party the losses stipulated in the contract terms. Only in that case, compensation could be recognized as the most effective protective measure for shareholders agreement parties and could be admitted as an essential guarantee of agreement fulfillment by its parties.

\section{Conclusions}

Research of the problem of civil and legal regulation of the shareholders agreements in Ukraine, the USA, Russia and Western European countries (by the example of Germany, Italy, Switzerland and France), led to the following conclusions.

1. The shareholders agreement - is an agreement concluded between the shareholders and is aimed at determining the procedure of actions, rights and obligations of the parties directly related to the management of ajoint stock company, profit distribution, implementation of the rights and obligations of the shareholders, the decision of "deadlock" situations, if the number of votes of shareholders, who have different points of view on the decision of any matter, is equal.

2. Objectives of the shareholders agreement - is to regulate the behavior of the shareholders in any given situation. For example, to predict the distribution of seats and the balance of power in choosing the next part of members of the executive authority or to define different restrictions on the sale and purchase of shares of a joint stock company, i.e., the prohibition to sell shares to a certain point or, conversely, the obligation to buy shares of other shareholders under certain events.

3. Generalizing analysis of the legislation and doctrinal sources of the considered systems of justice of European countries and Ukraine makes it possible to distinguish the most characteristic features for the notion of shareholders agreement. First, the shareholders agreement is concluded in regard to the rights of shareholders; secondly, it provides methods or the peculiarities of the implementation of the rights of shareholders, including those not under the law and the charter of the company; thirdly, such agreements are of relative nature - their action is spread only for the parties of obligations.

4. Indication of the purpose of the shareholders agreement in a regulatory form will make it possible to define its legal nature more precise, to make interpretation of the relevant norms regulating such agreements, to distinguish them as the legal construction from other similar agreements and to ensure prevention of abuse in exercising the rights by the shareholders.

5. In accordance with the legislation of European countries the shareholders agreement is concluded in a 
written form, in Switzerland and Germany it is possible to conclude it orally, but in limited cases. There are no additional requirements to the form of shareholders agreements, in particular there no registration requirements or notary registration of such agreements even if they supplement the provisions of the statute. We believe that shareholders agreements are to be concluded in a written form by drawing a single contract signed by the parties.

6. The relationships between shareholders settled by the shareholders agreement is not an analogue of corporate relations within a joint stock company. The joint stock company and other shareholders of that company may not be aware about the existence of the agreement. Therefore, we can not talk about its "normative feature" or in other words "generally binding character" for all shareholders of the company. The action of such an agreement is not extended to the sphere of functioning and activities of the company.

7. Measures of civil and legal liability applicable for the violation of the terms of the shareholders agreement are quite diverse. We believe that compensation is the most versatile and effective measure of liability for the obligations that derive from shareholders agreements, in particular such as to vote in a certain way at the general meeting, to coordinate the voting options with other shareholders, to agreed other actions related to the management, activity, reorganization and liquidation of the joint stock company due to the fact that the amount of compensation is determined by the parties and does not depend on the availability of damages, which can not be reduced by the decision of the court and can be used along with others measures of civil and legal liability.

8. The adjudgement to perform specifically is allowed in case of the violation of a shareholders agreement because it is not against the law in most cases and can be an effective mean of guaranteeing the rights of the shareholders. However, from a practical point of view, the real adjudgement of obligations, in case, if the object of a shareholders agreement is the obligation on voting procedure, will be ineffective mean to protect the interests of their parties.

\section{References:}

Abova T.E. (2013) "On the new approaches to the civil-law transactions regulation in Federal Law"On Amendments to Parts One, Two, Three, and Four of the Civil Code of the Russian Federation, as well as to certain legislative acts of the Russian Federation" draft", Regulation of private law social relations: tradition, modernity, perspective, (TOV «Bilotserkivdruk», Odesa), p. 41.

Aktiengesetz vom 6. September 1965 (BGBl. I S. 1089), Artikel 2 Absatz 49 (22 Dezember 2011) (BGBl. I S. 3044) URL: http://www.gesetze-im-internet.de/aktg/BJNR010890965.html

Art. 384, On Joint-Stock Companies (Law of Ukraine dated from September 17, 2008 No. 514-VI) 50(1) Bulletin of Verkhovna Rada of Ukraine (2008).

Belov V. A. (2013) Civil law. Special part. Relative Civil Law Forms: A Textbook for Bachelors Vol. IV (Jurajt, Moskow), $958 \mathrm{p}$.

Chionna V. V. (2008) La pubblicità dei patti parasociali. (Giuffrè, Milano), p. 2-4.

Christoph Weber (2000) Privatautonomie und Außeneinfluß im Gesellschaftsrecht Tübingen: Mohr Siebeck. (Zugl.: Mainz, Univ., Habil.-Schr., 1998/99), 92 p.

Die Zweimannaktiengesellschaft, Von Hans-Konrad Peyer (1963) Bern, and other.

Fischer (1953), GmbH-Rundschau (GmbHR), 65 p.

For example, in Swiss science the foundations of modern doctrinal understanding of shareholders agreements are reflected in following scientific studies: Eric Haymann, Aktienübernahmevereinbarungen zwischen Mehrheits und Minderheitsaktionären: ein Vorschlag zu einem wirksamen Minderheitenschutz, vor allem in kleinen und mittleren Aktiengesellschaften (Zugl.: Zürich, Univ., Diss., 1973).

Graham Stedman \& Janet Jones (1998), Shareholder's Agreements. p. 58-59.

Hans Jürgen Sonnenberger und Christian (2000) Autexier Einführung in das französische Recht von. Ausgabe: 3., neubearb. Aufl. Heidelberg: Verl. Recht und Wirtschaft, 190 p.

Hewitt I. (2016) Hewitt on Joint Ventures (Sweet \& Maxwell; 5th Revised edition), 166 p.

Hureev V. A. (2007) Problems of protecting the shareholders rights and interests in Russian Federation, (Wolters Kluwer, Moskow), 115 p.

Innominatverträge: Festgabe zum 60. Geburtstag von Walter R. Schluep hrsg. von Peter Forstmoser. (Polygraph. Verl Zürich: Schulthess, 1988), 373 p.

Karzhavyna N. S. (2007) "Shareholders' agreement as a way of corporate conflict overcome and the problem of its validity under the Russian”, Business Law, 4, at 8.

Lomakyn D. V. (2008) Corporate legal relationship: general theory and practice of its application in business entities (Statut, Moskow), p. 127-128.

Mayer D. (2006) “Grenzen von Aktionärsvereinbarungen”, 4 Mitteilungen des Bayerischen Notarvereins, der Notarkasse und der Landesnotarkammer Bayern, at 281. 
Medvedev Yu. L. (2014) Approximation of the law of Ukraine to the right of the European Union: conceptual categorical apparatus and methods of harmonization. Bulletin of the Lugansk State University of Internal Affairs named after E.O. Didorenka. No. 1, p. 52-59.

Müller R. (n.d) “Der Aktionärbindungsvertrag”, at. 4, URL: https://www.alexandria.unisg.ch/publications/54111/ L-en.

Osypenko K. O. (2010) "Agreements of participants (shareholders) in Russian and English", 4 Legislation, at 30-32. Pavlenko S., Sevruk V., Kobko Y. (2017) Training police officers in the conditions of reforming the system of education of the ministry of internal affairs of Ukraine in accordance with european standards. Science and Education. № 6, p. 142-150.

Petrova E., Khrapov M. (2008) “Shareholders' agreements regulation under the English Law”, Corporate Lawyer, 9, at $46-47$.

Resolution of Plenum of the Supreme Court of Ukraine dated from October 24, 2008 No. 13 "On Practice of Court Consideration of Corporate Disputes", 2 Commercial legislation bulletin (2009), at 7.

Romanova Yu. V. (2004) "Minority shareholders rights protection in Russian and foreign Civil Law", Journal of Russian Law, 10, at 125.

Schramm H.-J. (n.d) "Die rechtliche Erfassung von Aktionärsvereinbarungen”, URL: http://www.cac-civillaw.unibremen.de/publikationen.html

Spasybo-Fatieieva I. (2013) “Shareholders agreements", 12 Pravo Ukrainy, at 188.

Spasybo-Fateeva Y. V., Sybylev M. N., Jarockyj V. L. and other (2014), Kharkiv School of Civil Law: protection of subjective civil rights and interests, (Pravo, Kharkov), $459 \mathrm{p}$.

Stepanov D. Y. (2013) "Contractual freedom and Corporate Law", Civil law and modernity: col. of. art. in memory of M. Y. Brahynskii, (Statut, Moskow), 366 p.

"Stimmbindungsabsprachen in Kapitalgesellschafte: Rechtsvergleichung und internationales Privatrecht", Hansjürg Appenzeller, (Polygraph. Verl., Zürich: Schulthess, 1996), 58 p.

Suhanov E. A. (2014) "Corporate agreements in modern Russian and foreign law" Civil Society and the Development of Civil Law: col. of. art. for the anniversary of holder of habilitation degree in law, professor N. S. Kuznetsovoi, (ChAO «Yurydycheskaia praktyka», Kiev), $190 \mathrm{p}$.

Vasylieva V. A. (2012) "Corporate transactions: Theory and Practice", Contemporary issues of Civil, Family and Private International law (Matvieievski tsyvilistychni chytannia), (Alerta, Kyiv), 24 p..

Vinnyk O. M. (2010) "Corporate-management technologies based on shareholders agreements: statement of a question and defining of issues array", Yaroslav Mudryi National Law Academy of Ukraine Bulletin, 1, at 146. 